\title{
ESENSI AKAD MUDHARABAH DAN MUSYARAKAH PADA PERBANKAN SYARIAH DALAM MEWUJUDKAN KEADILAN EKONOMI
}

\author{
S a h b a n \\ Mahasiswa Program Doktor Ilmu Hukum PPs UMI \\ email : sahbanfakhumi@gmail.com
}

\begin{abstract}
The essence of mudharabah and musyarakah unite capital to labor (skill and entrepreneurs), which is always separate in conventional systems. In the profit and loss sharing agreement will be apparent the nature and spirit of togetherness and justice in receiving the benefits and bear the risk of losses in business activity.Mudharabah and musyarakah prevent unjustice behavior for people, it is a manifestation of man as caliph prosperity of the earth on the dimensions of the banking system. The substance and the principles contained in the profit and loss sharing agreement has been included in the National Banking Act. Skim mudharabah and loss has been practiced in various flying businesses in Islamic banking activities in order to prevent economy unjustice and realize the economic benefit.

Keywords : Mudharabah, Musyarakah, Economic Justice.
\end{abstract}

\begin{abstract}
Abstrak
Esensi mudharabah dan musyarakah menyatukan modal dengan tenaga kerja (keterampilan dan pengusaha), yang selalu terpisah dalam sistem konvensional. Dalam perjanjian pembagian keuntungan dan kerugian akan terlihat sifat dan semangat kebersamaan dan keadilan dalam menerima manfaat dan menanggung risiko kerugian dalam kegiatan bisnis. Mudharabah dan musyarakah mencegah perilaku tidak adil bagi manusia, itu adalah manifestasi manusia sebagai kekayaan khalifah. bumi pada dimensi sistem perbankan. Substansi dan prinsipprinsip yang terkandung dalam perjanjian bagi hasil dan kerugian telah dimasukkan dalam Undang-Undang Perbankan Nasional. Mudharabah dan kerugian skim telah dipraktikkan di berbagai bisnis penerbangan dalam kegiatan perbankan syariah untuk mencegah ketidakadilan ekonomi dan merealisasikan manfaat ekonomi.

Kata Kunci: Mudharabah; Musyarakah; Ekonomi Berkeadilan;
\end{abstract}

\section{A. PENDAHULUAN}

Islam merupakan agama yang sempurna, mengatur segala perilaku kehidupan manusia. Bukan hanya menyangkut urusan peribadatan saja, tetapi juga urusan sosial dan ekonomi diatur dalam Islam. Islam merupakan sistem hidup (way of life) yang harus diimplementasikan secara menyeluruh dalam seluruh aspek kehidupannya tanpa kecuali (Zainuddin, $2013: 1-2$ ).

Vol. 19 No. 2 November 2017 
Perbankan syariah merupakan suatu lembaga ekonomi Islam yang berbasis keuangan dengan fungsi sebagai organisasi perantara antara masyarakat yang kelebihan dana dengan masyarakat yang kekurangan dana yang dalam menjalankan aktivitasnya harus sesuai dengan prinsip-prinsip Islam. Bank syariah atau bank Islam juga berfungsi sebagai lembaga intermediasi yakni menghimpun dana dari masyarakat dalam bentuk simpanan dan menyalurkan kembali kepada masyarakat yang membutuhkannya dalam bentuk fasilitas pembiayaan dalam rangka meningkatkan taraf hidup rakyat (Muhammad, 2009: 4).

Bank Syariah lahir sebagai salah satu alternatif terhadap persoalan bunga Bank, karena Bank Syariah merupakan lembaga keuangan perbankan yang beroperasi dan produknya dengan prinsip dasar tanpa menggunakan sistem bunga dengan menawarkan sistem lain yang sesuai dengan syariah Islam. Dari sudut pandang kepentingan ekonomi, perbankan syariah yang menggunakan sistem mudharabah (profit sharing) dalam memperlancar roda perekonomian ummat dianggap mampu menekan terjadinya inflasi karena tidak adanya ketetapan bunga yang harus dibayarkan ke bank, juga dapat mengubah haluan kaum muslimin dalam setiap transaksi perdagangan dan keuangan yang sejalan dengan ajaran syariah Islam.

Mudharabah dan musyarakah atau yang sering dikenal dengan istilah profit and loss sharing (PLS) adalah dua model perkongsian yang direkomendasikan dalam Islam karena bebas dari sistem riba. Mudharabah dalam perbankan syariah memiliki landasan dalam Alqur'an, yaitu firman Allah swt. dalam QS al Muzammil/73 : 20.

Sejalan dengan perkembangan ekonomi dan menguatnya tuntutan umat Islam untuk memiliki bank yang berbasis syariah. Kelahiran Bank Syariah dengan salah satu akadnya mudharabah Syariah menandai era baru perbankan Syariah yang telah berpayung hukum jelas. Adanya Undang-Undang No. 21 Tahun 2008 tentang Perbankan Syariah, maka terdapat 2 (dua) undang-undang yang mengatur perbankan di Indonesia, yaitu UndangUndang No. 7 Tahun 1992 tentang Perbankan sebagaimana telah diubah dengan UndangUndang No. 10 Tahun 1998, dan Undang-Undang No. 21 Tahun 2008 tentang Perbankan Syariah.

Filosofi kelahiran perbankan syariah dapat dilihat pada konsideran bagian menimbang dari Undang-Undang Perbankan Syariah bahwa sejalan dengan tujuan pembangunan nasional Indonesia untuk mencapai terciptanya masyarakat adil dan makmur berdasarkan demokrasi ekonomi, dikembangkan sistem ekonomi yang berlandaskan pada nilai keadilan, kebersamaan, pemerataan, dan kemanfaatan yang sesuai dengan prinsip syariah. Dalam tulisan ini difokuakskan pada pada esensi akad mudharabah dan musyarakah pada perbankan syariah dalam mewujudkan keadilan ekonomi.

\section{B. ANALISIS DAN PEMBAHASAN}

\section{Nilai Tauhid}

Tauhid merupakan prinsip dasar dalam melakukan akad mudharabah. Pada hakikatnya setiap muslim harus melandasi dirinya dengan tauhid dalam menjalankan segala aktivitas kehidupannya, tidak terkecuali dalam bermuamalah (baca; beraktifitas 
dalam perbankan syariah). Artinya bahwa niat dasar ketika melakukan akad mudharabah diperbankan syariah haruslah berlandaskan pada prinsip tauhid, yaitu mengharapkan keridhaan Allah swt.

Tauhid menjadi pondasi utama ekonomi Islam, mempunyai hubungan kuat dengan konsep keadilan ekonomi dan persaudaraan. Ekonomi Tauhid yang mengajarkan bahwa Allah sebagai pemilik mutlak dan manusia hanyalah sebagai pemegang amanah, mempunyai konsekuensi, bahwa di dalam harta yang dimiliki setiap individu terdapat hakhak orang lain yang harus dikeluarkan sesuai dengan perintah Allah, berupa zakat, infaq dan sedekah dan cara-cara lain guna melaksanakan pendistribusian pendapatan yang sesuai dengan konsep persaudaraan umat manusia.

Menurut Muhammad Syafi'i Antonio (2001 : viii) Penerapan akad mudharabah dalam sistem Perbankan disamping mencerminkan semangat ilahiyah dalam berekonomi juga menjadi nilai tambah (value added) dari perspektif konsumen/nasabah. Tidak adanya nilai-nilai ilahiyah yang melandasi operasional perbankan dapat meluluhlantakkan perekonomian bangsa yang berasal dari perbankan.

Islam mensyariatkan kerja sama mudharabah untuk memudahkan seseorang, karena sebagian mereka memiliki harta, namun tidak mampu mengelolanya. Ada juga seseorang yang tidak memiliki harta, namun memiliki kemampuan untuk mengelola dan mengembangkannya. Maka syariat membolehkan adanya kerja sama ini untuk bisa saling mengambil manfaat.

Shahib al-mal (investor) memanfaatkan keahlian mudharib (pengelola). Sedangkan mudharib (pengelola) memanfaatkan harta. Maka dengan demikian terwujudlah kerja sama harta dan amal. Allah swt., tidak mensyariatkan satu akad, kecuali untuk mewujudkan kemaslahatan dan menolak kerusakan. Oleh karena itu, pengembangan modal dan peningkatan nilai suatu modal merupakan salah satu tujuan yang disyariatkan. Modal dapat berkembang hanya dengan dikelola dan diperniagakan dan tidak setiap orang yang mempunyai harta mampu berniaga. Begitu juga tidak setiap yang memiliki keahlian berdagang mempunyai modal. Maka masing-masing kelebihan itu dibutuhkan oleh pihak lain. Oleh sebab itu, mudharabah ini disyariatkan oleh Allah demi kepentingan kedua belah pihak.

\section{Prinsip Keadilan}

Prinsip kedua yang menjadi nilai-nilai dalam pengimplementasian akad mudharabah dan musyarakah dalam perbankan syariah adalah prinsip keadilan. Artinya bahwa bank syariah harus benar-benar bersikap adil, khususnya dalam membuat pola hubungan antara nasabah dengan nasabah, maupun antara nasabah dengan bank syariah, terkait dengan hak dan kewajiban masing-masing. Bank syariah tidak boleh mendzalimi nasabah dengan hal-hal yang akan menyulitkan atau merugikan nasabah.

Adapun asas dari semua akad adalah keadilan. Sebab, dengan keadilan itulah Allah swt. mengutus para Rasul dan menurunkan kitab-kitab suci-Nya. Allah swt. berfirman, Q.S. al-Hadid (57) Ayat 25, yang artinya : "Sesungguhnya Kami telah mengutuskan para Rasul dengan bukti-bukti, dan Kami telah menurunkan pada mereka al-Kitab serta timbangan (standar yang haq dan bathil), agar manusia menegakkan keadilan”. 
Filosofi dasar dari mudharabah dan musyarakah adalah untuk menyatukan capital dengan labour (skill dan enterpreneur) yang selama ini senantiasa terpisah dalam sistem konvensional. Dalam mudharabah dan musyarakah akan tampak jelas sifat dan semangat kebersamaan dan keadilan, Hal ini terbukti melalui kebersamaan dalam menanggung risiko kerugian yang dialami proyek dan membagikan keuntungan pada waktu ekonomi sedang booming

Menurut Yusuf Al Qardhawi (2000 : 52) nilai positif yang terkandung dalam akad mudharabah dan musyarakah adalah persamaan yang adil di antara pemilik modal dan pengelola, serta adanya tanggung jawab yang berani dalam memikul risiko. Islam tidak memihak kepada kepentingan pengusaha (interpreneur) dan mengalahkan pemilik modal, Islam juga tidak berat kepada pemilik modal sehingga menyepelekan kontribusi usaha. Keduanya berada dalam posisi seimbang. Inilah pengertian keadilan menurut Islam

Pada akad mudharabah dan musyarakah, asas keadilan benar-benar dapat diwujudkan dalam dunia nyata, yang demikian itu dikarenakan kedua belah pihak yang terkait, sama-sama merasakan keuntungan yang diperoleh. Sebagaimana mereka semua menanggung kerugian bila terjadi secara bersama-sama, pemodal menanggung kerugian materi (modal), sedangkan pelaku usaha menanggung kerugian non-materi (tenaga dan pikiran). Sehingga pada akad mudharabah dan musyarakah tidak ada seorangpun yang dibenarkan untuk mengeruk keuntungan tanpa harus menanggung risiko usaha.

Bank Syariah tidak mungkin menjalankan sendiri semua proyek yang dibiayai bank dan wajar jika menyalurkan pada pihak lain. Bank secara implisit telah mendapatkan persatuan atau izin dari pemilik modal (nasabah penyimpan dana). Nasabah penyimpan dana pasti menyadari bahwa bank sebagai lembaga keuangan yang kegiatannya usahanya diantaranya tidak terlepas dari kegiatan penyaluran dana. Bank adalah lembaga intermediasi antara mereka yang berlebihan dana dan mereka yang kekurangan dana, mudharabah dan musyarakah dalam praktik didasarkan atas suatu kontrak antara nasabah (debitur) dengan bank (kreditur). Adanya kontrak itu berarti telah terjadi penyerahan modal yang diikuti perintah untuk menjalankan usaha. Bank Syariah sebagai pengelola dana, dan sendiri maupun masyarakat bertindak sebagai pemegang amanah dan sebagai mudharib, disitu sisi dan shahibul maal dilain sisi. Dalam usaha menyalurkan dana, bank syariah menyediakan fasilitas pembiayaan yang aman dan memberikan hasil.

Apabila bank syariah memperoleh keuntungan maka dibagikan pada shahibul maal sesuai dengan prosentase yang telah disepakati. Mudharabah dan musyarakah antara bank (shahibul maal) dengan nasabah debitur mudharib (peminjam dana), yang akan dikelola oleh debitur dengan modal dari bank.

Akad mudharabah dan musyarakah telah banyak dipakai oleh masyarakat kita terutama di pedesaan, dalam bentuk kerjasama usaha seperti bidang pertanian. Dimana pemilik lahan bekerjasama dengan petani yang hasilnya nanti akan dibagi bersama. Contoh lain pemilik ternak bekerjasama dengan peternak yang hasilnya dibagi dua atau Paron (bahasa; jawa). Bukan persoalan mudharabah dan musyarakah lebih baik dari murabahah, karena keduanya diperbolehkan secara syariah. Sedangkan dalam perdagangan pola kerjasama atau mudharabah dan musyarakah adalah akad yang lebih cocok untuk diterapkan dan mempunyai nilai keadilan. Artinya, mengandung keadilan adalah ketika pedagang tersebut mempunyai keuntungan besar, berarti kita juga dapat

Vol. 19 No. 2 November 2017 
untung besar, kalau keuntungannya kecil kita juga ikut kecil. Bahkan ketika terjadi kecelakaan atau kerugian, kita juga ikut merasakan dengan catatan kecelakaan itu tidak disengaja seperti kebakaran maupun meninggal dunia.

Menurut Bachsan Mustofa (2003 : 49) Terkait dengan asas keadilan dalam sistem bagi hasil (Mudharabah dan musyarakah) di Bank Syariah, maka tidak akan lepas pada yang dinamakan asas hukum. Asas hukum berfungsi sebagai pondasi yang memberikan arah, tujuan serta penilaian fundamental, mengandung nilai-nilai dan tuntutan-tuntutan etis. Terkait dengan hal tersebut, dalam satu mata rantai, sistem, asas, norma dan tujuan hukum berfungsi sebagai pedoman dan ukuran atau kriteria bagi perilaku manusia.

Melalui asas hukum, norma hukum berubah sifatnya menjadi bagian suatu tatanan etis yang sesuai dengan nilai kemasyarakatan. Pemahaman tentang keberadaan suatu norma hukum (mengapa suatu norma hukum diundangkan) dapat ditelusuri dari "ratio legis" nya. Meskipun asas hukum bukan norma hukum, namun tidak ada norma hukum yang dapat dipahami tanpa mengetahui asas-asas hukum yang terdapat di dalamnya (Dyah Ochtorina Susanti, $2015: 5$ )

Keadilan adalah tujuan akhir sebuah sistem, yang terkait erat dengan fungsi sistem hukum sebagai sarana untuk mendistribusikan dan memelihara suatu alokasi nilai-nilai dalam masyarakat, yang ditanamkan dengan suatu pandangan kebenaran, yang secara umum merujuk kepada keadilan (Dyah Ochtorina Susanti, 2015 : 6). Terkadang hukum positif sepenuhnya menjamin rasa keadilan, dan sebaliknya rasa keadilan seringkali tidak memiliki kepastian hukum, sehingga komprominya adalah bagaimana agar hukum positif yang ada selalu merupakan cerminan dari rasa keadilan itu.

Adanya bentuk kerjasama dalam lintas kegiatan Islam seperti mudharabah dan musyarakah, sebagai konsep yang menjadi landasan untuk melaksanakan dalam hal berbisnis dan usaha hingga dalam pembagian yang akan diinginkan untuk kedua belah pihak atau lebih dapat terpenuhi dengan memenuhi proporsi apa yang ingin dikehendaki dalam kesepakatan yang telah dibuat.

Bentuk keadilan dari sistem mudharabah dan musyarakah tersebut akan menimbulkan akan saling adanya kepercayaan antara pihak yang terlibat dalam mudharabah dan musyarakah, terpenuhinya proporsi yang diharapkan oleh masingmasing pihak akan membuat pengelola akan melakukan dengan segenap kemampuannya dan pemodal sebagai pengontrol dalam aktivitas kerjasama tersebut.

Dalam ekonomi Islam, penegakan keadilan sosio-ekonomi dilandasi oleh rasa persaudaraan (ukhuwah), saling mencintai (mahabbah), bahu-membahu (takaful) dan saling tolong-menolong (ta'awun), baik antara si kaya dan si miskin maupun antara penguasa dan rakyat.

Islam mengganti sistem bunga yang menindas dengan profit sharing. Profit sharing (bagi hasil) yang diterapkan dalam ekonomi syari'ah jelas lebih berkeadilan. Bagi deposan, untung yang didapat adalah benar-benar hasil untung pekerja yang diberi modal. Sementara, bagi peminjam (yang juga pekerja) tidak merasa terbebani dengan bunga yang tinggi. Karena ia hanya membayarkan sejumlah untung yang ia dapat dari 
bekerja. Kalau untung banyak, ia akan membayar banyak bagi hasilnya. Kalau untung sedikit, ia pun akan membayar sedikit bagi hasilnya

\section{Prinsip Taawwun (Tolong Menolong)}

Dalam Islam, tolong-menolong adalah kewajiban setiap muslim. Sudah semestinya konsep tolong-menolong tidak hanya dilakukan dalam lingkup yang sempit. Untuk menjaga agar tolong-menolong ini selalu dalam koridor kebaikan dan takwa diperlukan suatu sistem yang benar-benar sesuai syariah.

Mudharabah dan musyarakah menerapkan prinsip tolong menolong karena melibatkan antara dua kelompok, yaitu pemilik modal (investor) yang mempercayakan modalnya kepada pengelola (mudharib) untuk di gunakan dalam aktivitas perdagangan. Mudharib dalam hal ini memberikan konstribusi pekerjaan, waktu dan mengelola usahanya sesuai dengan ketentuan yang di capai dalam kontrak, salah satunya adalah untuk mencapai keuntungan yang di bagi antara pihak investor dan mudharib berdasarkan proporsi yang telah di setujui bersama, namun apabila terjadi kerugian yang menanggung adalah pihak investor saja.

Konsep tolong menolong (taawun), dalam menghadapi ketidakpastian merupakan salah satu prinsip yang sangat mendasar dari ekonomi Islam yang dianggap dapat mendukung aspek keadilan. Keadilan merupakan aspek mendasar dalam perekonomian Islam. Penetapan suatu hasil usaha di depan dalam suatu kegiatan usaha dianggap sebagai sesuatu hal yang dapat memberatkan salah satu pihak yang berusaha, sehingga melanggar aspek keadilan.

Mudharabah dan musyarakah merupakan sarana tolong menolong antara sesama manusia. Adanya konsep seperti ini, berarti antara sesama nasabah telah mengimplementasikan saling tolong menolong, kendatipun antara mereka tidak saling bertatap muka.

Tolong-menolong ini menjadi salah satu nilai yang terkandung dalam ekonomi Islam. Menolong yang lemah, membantu orang yang memerlukan bantuan sudah sebuah kemestian. Para pelaku ekonomi Islam dituntut agar dapat membantu saudaranya keluar dari permasalahan yang dihadapi. Membantu masyarakat yang masih menikmati riba

menuju ke sistem yang islami atau syariah, juga dikategorikan sebagai bagian dari nilai tolong-menolong. Apalagi dapat membantu masyarakat ke luar dari lembah kemiskinan.

\section{Prinsip Kerjasama}

Sistem bagi hasil (profit and loss sharing) yang diterapkan dalam perbankan syariah seperti yang terdapat dalam mudharabah dan musyarakah merupakan praktik perkongsian yang sudah lazim digunakan sebelum Islam datang. Sebagaimana Lewis dan Algaoud mengutip pendapat Crone, Kazarian dan Cizaka, bahwa di Timur Tengah pra-Islam, kemitraan-kemitraan bisnis yang berdasarkan atas konsep mudharabah dan musyarakah berjalan berdampingan dengan konsep pinjam sistem bunga sebagai cara untuk membiayai berbagai aktivitas ekonomi (Mervyn Lewis dan Latifa Algaoud, 2004 :

14) Kemudian setelah Islam datang, semua transaksi keuangan yang berbasis riba

Vol. 19 No. 2 November 2017 
(Sayyid Sabiq, 2006 : 173) dilarang dan semua dana harus disalurkan atas dasar bagi hasil (profit and loss sharing).

Transaksi Mudharabah dan musyarakah merupakan akad kerjasama usaha antara pemilik dana dan pengelola dana untuk melakukan kegiatan usaha. Institusi pemilik dana membiayai seluruh modal usaha yang dibutuhkan oleh institusi yang mengelola usaha tersebut. Pengelola dana berkewajiban melaksanakan usaha sesuai dengan akad yang disepakati, agar dapat menghasilkan keuntungan sesuai dengan yang diproyeksikan.

Kerjasama diantara sesama manusia adalah sebuah bentuk untuk memenuhi kebutuhan hidup dan mencapai kemajuan bersama dalam hidup. Kerjasama pada dasarnya adalah merealisasikan unsur tolong menolong sesama manusia yang dianjurkan dalam Islam, selama tolong menolong tersebut membawa kebaikan dan menghindarkan dari kemungkaran.

Antara nasabah dengan bank syariah terjalin kerjasama, tergantung dari akad apa yang digunakannya. Adanya akad mudharabah dan musyarakah terjalin kerjasama antara bank syariah dengan nasabah. Apabila dari dana tersebut terdapat keuntungan, maka akan dibagi berdasarkan nisbah yang telah disepakati, misalnya $40 \%$ untuk nasabah syariah dan $60 \%$ untuk bank syariah. Ketika kerjasama terjalin dengan baik, nasabah menunaikan hak dan kewajibannya, demikian juga bank syariah menunaikan hak dan kewajibannya secara baik, maka akan terjalin pola hubungan kerjasama yang baik pula dan akan membawa keberkahan pada kedua belah pihak.

Mudharabah dan musyarakah ini disyariatkan oleh Allah swt. demi kepentingan kedua belah pihak. Islam mensyariatkan kerja sama mudharabah untuk memudahkan seseorang, karena sebagian mereka memiliki harta, namun tidak mampu mengelolanya. Ada juga seseorang yang tidak memiliki harta, namun memiliki kemampuan untuk mengelola dan mengembangkannya. Maka syariat membolehkan adanya kerja sama ini untuk bisa saling mengambil manfaat.

Menurut Imam al-Marghinani al-Hanafy, bahwa akad mudharabah dihalalkan, karena benar-benar diperlukan oleh umat manusia, karena di antara manusia ada orangorang yang kaya akan harta benda, akan tetapi ia tidak pandai untuk mengelolanya. Sebagaimana di antara mereka ada orang-orang yang lihai dalam mengelola kekayaan, akan tetapi mereka miskin tidak memiliki modal usaha. Sangat urgen untuk disyariatkan transaksi semacam ini, agar kemaslahatan kedua belah pihak, yaitu orang yang kaya (tapi tidak berpengalaman) dan orang yang cerdik (tapi tidak memiliki modal), orang yang miskin (tapi lihai) dan orang yang dungu (tapi kaya) dapat terwujud. (http://realsyariah.wordpress.com/2011/05/16/ diakses pada 17 Juli 2016)

\section{Prinsip Amanah}

Amanah merupakan salah satu prinsip yang sangat penting. pada hakikatnya kehidupan ini adalah amanah yang kelak harus dipertanggung jawabkan dihadapan Allah SWT. Menurut Triyuwono bahwa tujuan dari organisasi menurut Islam adalah menyebarkan rahmat seluruh alam (Iwan Triyuwono, 2000 : 282). Tujuan ini secara 
normatif berasal dari keyakinan Islam dan misi hidup sejati manusia sebagai khalifah di bumi sebagai penerima amanah dari pemberi amanah ialah Allah swt.

Perspektif amanah yang dikemukakan oleh Triyuwono dijadikan sebagai metafora dalam menjelaskan tujuan dibangunnya suatu organisasi dalam menyebarkan rahmat bagi seluruh alam, tentunya dapat dilihat atau dipantau dari iklim atau suasana yang ada di dalam organisasi tersebut, harapan keberadaan organisasi tersebut dapat memberikan iklim humanis dan transendental dalam kehidupan organisasi. Oleh karena itu, keberadaan perbankan syariah yang pada prinsipnya secara operasional berdasarkan pada Alqur'an dan hadis, tentunya peran dan tanggungjawabnya harus sesuai dengan perspektif amanah, dimana baik manusia secara individu dan organisasi dapat menyebarkan rahmat bagi seluruh alam (Iwan Triyuwono, $2000: 263$ ).

Atas dasar prinsip di atas, pihak pemilik modal (shahibul mal) pada prinsipnya tidak dapat menuntut jaminan apapun dari mudharib untuk mengembalikan modal atau modal dengan keuntungan. Jika pihak shahibul mal mempersyaratkan pemberian jaminan dari nasabah pengelola (mudharib) dan menyatakan hal ini dalam syarat kontrak, maka kontrak mudharabah tersebut menurut mayoritas ulama (jumhur ulama) tidak sah (ghair shahih) karena bertentangan dengan prinsip dasar akad amanah dalam mudharabah.

Pemegang amanah terhadap dana mudharabah dari penyandang dana dituntut untuk menjaganya dan mengusahakannya dalam investasi sesuai dengan ketentuan yang telah disepakati bersama mengembalikannya jika usaha telah selesai. Dalam mudharabah mudharib menguasai seluruh modal agar dapat dikelola secara efektif, dan mengelola modal sesuai dengan keinginannya (Abd. Shomad, 2005 : 368). Shahibul maal tidak dapat menentukan bagaimana modal itu harus dikelola, karena akan membuat pengelola usaha tidak dapat menguasai modal secara mutlak, dan tidak mampu mengelola modal (Abd. Shomad, $2000:$ 368).

Pada prinsipnya dalam mudharabah shahibul maal tidak menetapkan syarat-syarat tertentu kepada mudharib. Namun demikian, apabila dipandang perlu, shahibul maal boleh menetapkan batasan-batasan guna menyelamatkan modalnya dari kerugian. Apabila mudharib melanggar batasan-batasan ini, maka mudharib harus bertanggung jawab apabila terjadi kerugian.

\section{Prinsip Saling Ridha (an Taradhin)}

Prinsip ini didasarkan pada ketentuan QS. An-Nisa (4) Ayat 29 dan Hadis Nabi Muhammad saw. yang mengemukakan prinsip an-taradhin (rela sama rela). Hal ini berarti para pihak harus bebas dalam bertransaksi, lepas dari paksaan dan tekanan (Hamzah Ya'cub, $1984:$ 79).

Prinsip an-taradhin dapat dimaknai bahwa semua kontrak yang dilakukan oleh para pihak harus didasarkan kepada kerelaan semua pihak yang membuatnya. Kerelaan para pihak yang berkontrak adalah jiwa setiap kontrak yang Islami dan dianggap sebagai syarat terwujudnya semua transaksi. Jika dalam suatu kontrak asas ini tidak terpenuhi maka kontrak yang dibuatnya telah dilakukan dengan cara yang batil. Kontrak yang 
dilakukan itu tidak dapat dikatakan telah mencapai sebuah bentuk usaha yang dilandasi saling rela antara pelakunya jika didalamnya terdapat unsur tekanan, paksaan, penipuan atau ketidak jujuran dalam pernyataan.

Prinsip antaradin, yakni pemindahan hak kepemilikan atas harta yang dilakukan secara sukarela. Dalam transaksi apapun, aspek an-taradhin atau saling meridhai harus selalu menyertai. Nasabah ridha dananya dikelola oleh bank yang amanah dan profesional, sementara bank ridha terhadap amanah yang diembankan nasabah dalam mengelola kontribusi. Berdasarkan prinsip inilah, terjadi tolong menolong dan memiliki arti yang luas dan mendalam, karena semuanya menolong dengan ikhlas dan ridha, bekerjasama dengan ikhlas dan ridha, serta bertransaksi dengan ikhlas dan ridha pula. Untuk menunjukan sikap menerima/ridha pihak-pihak (an-taradhin) yang terlibat dalam transaksi tidak perlu dengan ucapan ijab qabul yang formalistik.

Hukum yang berlaku dalam akad mudharabah, sebenarnya kembali kepada keridhaan kedua belah pihak. Prinsipnya adalah 'an taradhin, yaitu kedua belah pihak saling ridha yang disepakati di awal perjanjian. Asas kerelaan ('an taradhin minkum) dalam mu'amalah sangat penting. Keabsahan suatu aktifitas mu'amalah turut dipengaruhi oleh aspek ini. Sesungguhnya implementasi ijab-qabul mencuat dalam penerapan prinsip ini (Efrinaldi, http://efrinaldi. multiply.com/journal, diakses pada 27 Juni 2016).

\section{Prinsip Menghindari Riba}

Mudharabah merupakan bentuk kerjasama sebagai sarana merekonstruksi dan reorganisasi dalam dunia perbankan Muhammad Nejatullah Siddiqi, 1985 : 9) Maka dapat dikatakan mudharabah merupakan alat untuk mencegah timbulnya riba. Mudharabah dengan sistem bagi hasil merupakan awal pertumbuhan perbankan Syariah. Bahkan undang-undang perbankan menyebut bagi hasil untuk membedakan dengan bank yang menggunakan instrumen bunga.

Riba merupakan bentuk transaksi yang harus dihindari sejauh-jauhnya khususnya dalam berbisnis karena riba merupakan sebatil-batilnya transaksi muamalah. Setiap usaha bisnis pasti membutuhkan modal usaha berupa dana segar. Dalam sistem sekuler, pendanaan modal biasanya didapat dari pinjaman bank konvensional yang dipastikan menerapkan sistem riba. Padahal riba telah $100 \%$ haram dalam syariat Islam. Di sisi lain, hampir mustahil menjalankan usaha tanpa pinjaman modal, sebagai alternatif untuk menghindari riba, maka digunakan sistem bagi hasil, yang kemudian dikenal dengan istilah mudharabah. Jadi mudharabah adalah sebuah sistem untuk mendapatkan modal usaha tanpa harus terjebak dengan sistem riba. Caranya adalah dengan menyertakan pemilik dana segar dalam sebuah usaha, sehingga dana segar itu didapat bukan dengan cara dipinjam, melainkan dengan usaha bersama.

Di perbankan Syariah dikenal dengan tabungan dan atau deposito mudharabah. Mudharabah sendiri adalah jenis akad dimana pada saat penyaluran dananya bank memberikan dana sebagai pemodal kepada orang/pengusaha yang mempunyai keahlian dibidang usahanya. Keuntungan dari usaha dibagi hasil dengan bank yang kemudian 
akan dibagi hasil juga dengan anda sebagai penabung. Oleh sebab itu, mudharabah dikenal dengan dengan konsep bagi hasil, dan deposito mudharabah menggunakan konsep bagi hasil ini untuk menggantikan bunga yang riba tersebut.

Adanya pelarangan riba, Islam berusaha membangun sebuah masyarakat berdasarkan kejujuran dan keadilan (Masyhuri, 2005 : 138) Keadilan dalam konteks ini memiliki dua dimensi, yaitu pemodal berhak untuk mendapatkan imbalan, tetapi harus sepadan dengan resiko dan usaha yang dibutuhkan, dan imbalan yang didapat ditentukan oleh keuntungan dari proyek yang dimodalinya. Yang dilarang dalam Islam adalah keuntungan yang ditetapkan sebelumnya.

\section{Prinsip Menghindari Maisir}

Dalam Penjelasan Pasal 2 huruf b, Undang-Undang Perbankan Syariah, maisir yaitu transaksi yang digantungkan kepada suatu keadaan yang tidak pasti dan bersifat untunguntungan. Pegertaian yang sama juga diatur dalam peraturan Bank Indonesia No 7/46/PBI/2005 pada Penjelasan Pasal 2 Ayat 3 menjelaskan bahwa maysir adalah transaksi yang mengandung perjudian, untung-untungan atau spekulatif yang tinggi.

Maisir dalam transaksi diperbankan yaitu transaksi yang mengandung unsur perjudian, atau spekulasi yang tinggi. Bank syariah tidak diperkenankan melakukan transaksi pada sektor atau bidang dengan tingkat spekulasi yang tinggi atau judi. Akibat tindakan spekulasi ini akan menimbulkan zero sum game, yang artinya satu pihak mendapat keuntungan dengan cara mengorbankan/menzalimi pihak lain tanpa ada pengganti nilai tambah yang setara dengan pengorbanannya tersebut.

Ekonomi Islam berbasis pada paradigma dimana keadilan ekonomi menjadi tujuan utama sementara transaksi maisir adalah transaksi yang bersifat untung-untungan. Artinya tidak pasti berapa nilai yang akan didapat. Karena sifatnya untung-untungan maka transaksi ini menafikan aspek keadilan ekonomi.

\section{Prinsip Menghindari Gharar}

Pelarangan gharar semakin relevan untuk era modern ini karena pasar keuangan modern banyak mengandung usaha memindahkan risiko (bahaya) pada pihak lain (dalam asuransi konvensional, pasar modal dan berbagai transaksi keuangan yang mengandung unsur perjudian). Dimana setiap usaha bisnis pasti memiliki risiko dan tidak dapat dihindari. Sistem inilah yang dihapus oleh Islam agar proses transaksi tetap terjaga dengan baik dan persaudaraan tetap terjalin dan tidak menimbulkan permusuhan bagi yang melalukan transaksi dalam pasar keuangan.

Unsur gharar (ketidakpastian, spekulasi) tidak diperkenankan. Kedua belah pihak harus mengetahui dengan baik hasil yang akan mereka peroleh dari sebuah transaksi. Para ilmuwan ekonomi membedakan istilah ketidakpastian dan risiko. Menurut Knight, risiko menguraikan situasi dimana kemungkinan dari suatu peristiwa (kejadian) dapat diukur.

Diantara hikmah larangan gharar adalah, karena nampak adanya pertaruhan dan menimbulkan sikap permusuhan pada orang yang dirugikan. Yakni bisa menimbulkan 
kerugian yang besar kepada pihak lain sehingga keadilan ekonomi tidak terwujud. Larangan ini juga mengandung maksud untuk menjaga harta agar tidak hilang dan menghilangkan sikap permusuhan. Apabila permusuhan telah terjadi maka dapat mengakibatkan ketidakadilan didalamnya.

\section{PENUTUP}

Esensi mudharabah dan musyarakah mengandung nilai tauhid dan prinsip keadilan, taawun, kerjasama, amanah, saling ridha, menghindari riba, menghindari maisir, menghindari gharar. Kesemua nilai dan prinsip tersebut mendorong terwujudnya keadilan ekonomi dalam akad mudharabah dan musyarakah pada Perbankan Islam. Skim akad mudharabah dan musyarakah telah dipraktikkan dalam berbagai kegiatan bisnis dalam perbankan syariah yang dapat menguntungkan kedua belah pihak. Pemilik modal (shahibul mal) memanfaatkan keahlian pengelola (mudharib), sedangkan mudharib (pengelola) memanfaatkan harta pemilik modal dan dengan demikian terwujudlah sebuah kerja sama yang dapat menciptakan keadilan ekonomi.

Upaya yang harus dilakukan adalah perlunya pengambilan langkah-langkah yang strategis dalam menjadikan akad mudharabah dan musyarakah sebagai sebagai solusi untuk meningkatkan kesejahteraaan umat yang berdasar pada keadilan ekonomi.

\section{DAFTAR PUSTAKA}

Abd. Shomad et al., Profit Loss Sharing Principle Dalam Hukum Ekonomi Islam, Laporan Penelitian Lembaga Penelitian Universitas Airlangga, 2000, h. 368.

2005. “Karakteristik Ilmu Fiqh Muamalah”, Juridika, Vol. 20 No. 2, Maret-April.

Anonim. "Mengenal Akad Mudharabah" http://realsyariah.wordpress.com/ 2011/05/16/ mengenal-akad-mudharabah/ diakses pada 17 Juli 2016.

Bachsan Mustofa. 2003. Sistem Hukum Indonesia Terpadu. Bandung: Citra Aditya Bakti.

Dyah Ochtorina Susanti. 2015. Percikan Pemikiran Hukum. Yogyakarta: Buku Litera.

Efrinaldi. "Prinsip-Prinsip Sistem Ekonomi Islam" http://efrinaldi. multiply.com/journal?\&page_start=20 diakses pada 27 Juni 2016.

Hamzah Ya'cub. 1984. Kode Etik Dagang Menurut Islam Pola Pembinaan Hidup dalam Berekonomi. Bandung: CV. Diponegoro.

Iwan Triyuwono. 2000. Organisasi dan Akuntansi Syari'ah. Jakarta: LKis 2005. “Akuntansi Syari'ah dan Koperasi: Mencari Bentuk dalam Bingkai Metafora Amanah”, Jurnal Akuntansi dan Auditing Indonesia, Vol.1, No. 1.

Masyhuri (Ed). 2005. Teori Ekonomi dalam Islam. Yogyakarta: Kreasi Wacana.

Mervyn Lewis dan Latifa Algaoud. 2004. Perbankan Syariah: Prinsip, Praktek, dan Prospek. Jakarta: PT. Serambi Ilmu Semesta.

Muhammad. 2005. Kontruksi Mudharabah dalam Bisnis Syariah. Yogyakarta: BPFEVol. 19 No. 2 November 2017 
Yogyakarta.

2009. Model-model Akad Pembiayaan di Bank Syariah. Yogyakarta: UII Press

Muhammad Nejatullah Siddiqi. 1985. Partnership and Profit Sharing in Islamic Law. New York: The Islamic Foundation Leicester.

Muhammad Syafi'i Antonio. 2001. Bank Syariah: dari Teori ke Praktik. Jakarta: Gema Insani Press.

Sayyid Sabiq. 2006. Fiqih Sunnah Jilid IV. Jakarta: Pena Pundi Aksara.

Yusuf Al Qardhawi. 2000. Bunga Bank Haram. Jakarta: Akbar Media Eka Sarana

Zainuddin. 2013. Hukum Zakat: Perspektif Normatif, Kesejahteraan dan Keradilan Sosial. Makassar: Alauddin University Press. 